\title{
PSEUDOCOLONIAL BEHAVIOR OF BIVALVES IN MESOZOIC CARBONATE BUILDUPS: SWITCHING GUILDS
}

\author{
FRASER*, Nicole, and BOTTJER, David J., Department of Earth Sciences, University \\ of Southern California, Los Angeles, CA 90089-0740, U.S.A.
}

In the Mesozoic, even before the rise of rudists, bivalves made forays into carbonate buildups. Bivalves first entered the buildup environments as solitary dwellers, living upon the reef surface or within its interstices, such as the modern Tridacna. Later in the Mesozoic some bivalves switched from the dweller to constructor guilds, exemplified by the rudists in the Cretaceous.

This evolution from one guild to another requires changes in bauplan, food source or space utilization. In carbonate buildups, the constructor guild contains organisms that have rigid skeletons intergrown in life position, as well as rapid growth rates that allow development of positive relief for utilization of the water column directly above as a source of food. For solitary bivalves, the invasion of the constructor guild allowed them to benefit from the ecological advantages of dense packing but required changes in space utilization and bauplan. These changes have been achieved by gregarious or pseudocolonial behavior. In modern bivalve buildups, gregarious behavior is attained by strong larval selection and rapid post-larval growth rates. Suitable shell morphologies for dense packing are potentially a barrier towards development of gregarious behavior.

The level of pseudocolonial bivalve behavior may be measured in the fossil record using packing potential and spatial integration. Packing potential, or the number of organisms that can "fit" per unit area, is calculated from shell morphology. Using transect data, spatial integration is measured by the amount or lack of interstitial material between bivalves or other organisms. Eight Mesozoic buildup types of bivalves are scored for potential packing and spatial integration: megalodonts, "Black Marble Quarry bivalves," lithiotids, chondrodontids and three varieties of rudists - petalodontids, caprinids and monopleurids.

The data present a continuum from solitary to pseudocolonial behavior. Those with strongly solitary behavior, or dwellers, are typified by megalodonts and monopleurids. Chondrodontids, caprinids and "Black Marble Quarry bivalves" are gregarious with clustered distributions, and are intermediate between constructor and dwelling guilds. Constructor guild bivalves with strongly pseudocolonial behavior include lithiotids and petalodontids.

Low diversity, high density frameworks constructed of bivalves are common in modern shallow, turbid bights of variable salinity where they appear to be protected from destruction by high surf and stenohaline predators. However, some Mesozoic constructor guild bivalves exhibited high density in environments with high diversity, unlike their modern counterparts. Thus, in the Mesozoic the third factor of guild determination, food source, may have been altered (e.g. from suspension feeding to photosymbiosis), although it cannot be documented at this time. Nevertheless, the alteration of bauplan and space utilization of bivalves to erect growth and pseudocolonial behavior culminated in the invasion of the constructor guild. 